\title{
Comparative Quantitative and Qualitative Attributes of the Surface Respiratory Macrophages in the Domestic Duck and the Rabbit
}

\author{
Atributos Cualitativos, Cuantitativos y Comparativos de los Macrófagos \\ de la Superficie Respiratoria en el Pato Doméstico y el Conejo
}

"P. M. Mutua; "M. M. Gicheru; **A. N. Makanya \& ${ }^{* *}$ S. G. Kiama

MUTUA, P. M.; GICHERU, M. M.; MAKANYA, A. N. \& KIAMA, S. G. Comparative quantitative and qualitative attributes of the surface respiratory macrophages in the domestic duck and the rabbit. Int. J. Morphol., 29(2):353-362, 2011.

SUMMARY: In mammals, surface respiratory macrophages (SM) are known to play a foremost role in protecting the respiratory system by providing first line of defense through engulfing pathogens and particulate matter respired with air. It has been reported that the pulmonary cellular defense system of domestic birds is inadequate. In particular, low number of SM and even lack of the cells in a healthy avian respiratory system have been associated with susceptibility of domestic birds to respiratory diseases. In an endeavor to resolve the existing controversy, the quantitative and qualitative attributes of the surface respiratory macrophages of the domestic duck and of the domestic rabbit were compared under similar experimental conditions. Quantitatively, the rabbit SM were on average approximately fourteen times more than the duck SM. The SM were found to have comparable diameters measuring about $12 \mu \mathrm{m}$ in the duck and $13 \mu \mathrm{m}$ in the rabbit. Similarly, the duck and the rabbit SM were structurally similar. Typically, they were round granular cells possessing filopodial extensions and variable electron dense bodies in the cytoplasm. The phagocytic capacity measured using polystyrene particles revealed that the duck SM had a higher phagocytic capacity than the rabbit SM. The volume density of the engulfed polystyrene particles, i.e. the volume of the particles per unit volume of the cell was estimated at $20 \%$ in the duck and $9 \%$ in the rabbit. These results suggest that the comparatively low numbers of SM in domestic birds may contribute to susceptibility of the birds to diseases. However, given the high phagocytic capacity of the avian SM, susceptibility of the domestic birds may not be due to dearth of the SM alone but some other factor (s) such as persistent exposure of the birds to particulate matter which is known to reduce robustness of the SM may be involved.

KEY WORDS: Avian; Cellular defense; Lung; Phagocytosis; Rabbit; Surface macrophages.

\section{INTRODUCTION}

The respiratory systems have evolved either by evagination or invagination of certain body parts. The factors that determine the design of a respiratory system include, among others, the physiochemical characteristics of the respiratory medium used, the nature of the habitat occupied, and the lifestyle pursued (Maina, 1994). To promote gas exchange by diffusion, extensive respiratory surface areas with thin air - blood tissue barriers were contrived. Underscoring the expansive respiratory surface area and the extreme thinness of the blood-gas barrier in the human lung, Gehr et al. (1990) aptly drew analogies respectively to the square footage of a tennis court and to a fractional measurement of the thickness of an air-mail paper. Pulmonary bioengineering is inherently paradoxical: while vast surface area and thin tissue barrier enhance gas exchange, on the downside, the expansive and close proximity of the respiratory media undesirably makes the gas exchangers primary portals of entry of pathogenic microorganisms, harmful particulates, and toxic gases.

The role(s) that particulates play in initiating or aggravating pulmonary diseases is now well understood (Schwartz, 1993; Peters et al., 1997; Brunekreef \& Holgate, 2002). In a 24-hour-day (Brain, 1996), the human lung filters about 20,000 L of air. Depending on the severity of environmental pollution, with each breath, air containing thousands of particles and different kinds of allergens is inhaled. Despite this threat, the respiratory surface remains sterile. This is because it is protected from infection by a

* Department of Zoological Sciences, Kenyatta University, Nairobi, Kenya.

** Department of Veterinary Anatomy and Physiology, University of Nairobi, Nairobi, Kenya. 
formidable arsenal of mechanical and cellular defenses supplemented when necessary by inflammatory and immune responses (Skerret, 1994).

The fortifications that maintain the high degree of 'cleanliness' include: a) aerodynamic filtration that causes deposition of particles along the branched airway system (Brown et al., 1997: Geiser et al., 2003), b) a physical barrier that comprises of a subaqueous phase, a surfactant, and a blood-gas (tissue) barrier (Schürch et al., 1990; Gehr et al., 1996; Maina \& West, 2005), c) efficient mucocillary escalator system (Lippmann \& Schlesinger, 1984), d) phagocytic and freely motile surface respiratory macrophages (Warheit \& Harsky, 1993; Nicod, 2005), e) epithelial lining well endowed with tight junctions (Harkema et al., 1991; Godfrey, 1997; Nicod), f) phagocytic respiratory epithelium, especially in birds (Maina \& Cowley, 1998; Nganpiep \& Maina, 2002), and g) strategically placed mucosal and bronchial associated lymphoid tissue that is involved in dissolution and antibody labeling of foreign particulates (Anderson et al., 1966; Fagerland \& Arp, 1990; Reese et al., 2006). Occasionally, depending on the particular etiologic agent and specific defects in the host defenses, with severe consequences, the defenses are overwhelmed.

Meaningful understanding of how, where, and when pulmonary defenses are breached and devastated by various pathogenic agents and particulates now exists in mammals (Dockery et al., 1992; Oberdörster et al., 1994). However, regarding birds, relatively little is known about the cellular defenses of the respiratory system (Brown $e t$ al.; Reese $e t$ $a l$.$) . This state of affairs exists albeit the facts that in the$ poultry industry, respiratory diseases cause immense economic losses (Currie, 1999)

Since phagocytosis is the most important defense mechanism in all phyla of the animal kingdom (van Oss, 1986; Nicod), it is particularly important that the contribution of the SM in the clearance of particles and neutralization of pathogens in the lung should be well understood. Paucity (Toth et al., 1988; Fulton et al., 1990; Maina \& Cowley; Kiama et al., 2008) and even lack of SM (Stearns et al., 1987; Klika et al., 1996; Lorz \& Lopez, 1997) have been reported in the healthy avian lung. Investigators like Klika et al. and Spira (1996) have alleged that birds are highly susceptible to pulmonary infections. However, data on the phagocytising attributes of the avian SM are scarce and inconclusive (Kiama et al., 2008). This study has taken the inquiry further: the SM of the duck lung, were harvested, counted and challenged with polystyrene particles and comparison made with corresponding cells from the rabbit lung, a mammal of equivalent weight, to find out whether the avian SM differ from those of mammals.

\section{MATERIAL AND METHOD}

Pulmonary lavage of the avian respiratory system. Surface respiratory macrophages (SM) were obtained from the respiratory (lung-air sac system) of seven mature specimens of the domestic duck, Anas platyrhynchos as described by Nganpiep \& Maina and Kiama et al. (2008). Briefly, ducks were killed by intravenous injection of an overdose of pentobarbitone sodium (Euthanase ${ }^{\circledR}$ ) into the brachial vein. The trachea was then exposed and cannulated with sterile cannula attached to a funnel. Sterile pre-warmed $\left(40^{\circ} \mathrm{C}\right)$ phosphate buffered saline (PBS) was poured down the respiratory system from a height of $30 \mathrm{~cm}$. During instillation, the coelomic cavity was gently massaged to expel air in order to ensure penetration of PBS into all air spaces, including the air sacs. The instilled fluid was left in the respiratory system for 5 minutes and thereafter aspirated with a $50 \mathrm{ml}$ syringe. The recovered lavage fluid was centrifuged and pelleted respiratory surface macrophages re-suspended in sterile RPMI-1640 cell-culture medium. Five washes were performed per duck.

Bronchoalveloar lavage of the rabbit. Seven mature domestic rabbits, Oryctologus cuniculus were anaesthetized with intraperitoneal injection of ketamine hydrochloride (65 $\mathrm{mg} / \mathrm{kg}$ ) followed by intraperitoneal injection of pentobarbitone. The dosage was adjusted to reach deep anesthesia. The trachea was exposed, tracheotomy performed, and a cannula introduced and tightly fixed with a thread. A pneumothorax was created before the bronchoalvelor lavage procedure was started. The procedure consisted of five washes ( $25 \mathrm{ml}$ per wash) of the lungs with $\mathrm{Ca}+2$ and $\mathrm{Mg}+2$ free PBS. The total recovered lavage fluid was centrifuged and the pellet re-suspended in sterile cell culture medium (RPMI-1640).

Counting of the surface respiratory macrophages. The hemocytometer chambers were charged by drawing $200 \mu \mathrm{l}$ from the concentrated lavage fluids using a micropipette. Counting of SM was restricted to the cells that were identified as morphologically round or slightly amorphous, refractile, frequently granular cells.

In vitro viability of the surface respiratory macrophages. Viability of the harvested respiratory surface macrophages from the duck and the rabbit were determined by using trypan blue exclusion test. For every animal, a mixture of $50 \mu \mathrm{l}$ of cell suspension, $270 \mu \mathrm{l}$ of PBS and $180 \mu \mathrm{l}$ of trypan blue ( $0.5 \%$ in physiological saline) were prepared in sterile eppendorf tube and $200 \mu \mathrm{l}$ drawn from the mixture and charged into a hemocytometer. All dead cells contained blue dye in their cytoplasm. 
Phagocytosis of polystyrene particles. The duck and the rabbit SM were washed twice in PBS and re-suspended in fresh RPMI-1640 medium at a concentration of $1 ¥ 106$ per milliliter. The cells were co-cultured with polystyrene microspheres of $6 \mu \mathrm{m}$ diameter in sterile eppendorf tubes at a concentration of about 100 microspheres per cell for 5 hours. The tubes were shaken regularly to avoid sedimentation of the cells and the particles.

\section{Processing SM for transmission electron microscopy.}

Surface respiratory macrophages were washed three times in PBS and re-suspended in $2.5 \%$ phosphate buffered glutaraldehyde solution. The glutaraldehyde fixed cells were centrifuged and post-fixed in $1 \%$ osmium tetroxide in 0.1 M sodium-cacodylate buffer. This was followed by dehydration in graded series of ethanol $(70 \%, 80 \%, 90 \%$, and $100 \%$ twice) and gradual replacement of ethanol with propylene oxide before infiltrating and embedding the cells in epoxy resin.

Semi-thin and ultrathin sections were cut using a Reichert ${ }^{\circledR}$ ultramicrotome. The ultra-thin sections were picked on 200-wire mesh copper grids, stained with uranyl acetate, counterstained with lead citrate, and observed with a Philip 201C transmission electron microscope under an accelerating voltage of $60 \mathrm{kV}$. The semi-thin sections were collected on glass slides, stained with $0.5 \%$ toluidine blue, viewed, and photographed under a light microscope.

\section{Estimation of the diameters of the SM and the volume} density of the phagocytized particles

The diameters of the SM of the duck and the rabbit were determined under an ocular graticule with a linear scale at a magnification of $¥ 100$. In each field, to avoid bias, the cells were singled out at random. Only the diameters of the cells at the four corners of the fields and one at the middle were measured.

Volume density of the phagocytised particles in the $\mathrm{SM}[\mathrm{Vv}(\mathrm{p}, \mathrm{c})]$ was determined as the ratio of the total volume of phagocytised particles to the cell volume. The ratio was estimated by point counting on the plane sections as described by Kiama et al. (2001, 2008). Briefly, one ultra-thin section was randomly sampled from each processed block of cell pellets and 35 fields systematically sub-sampled from each section. The corresponding micrographs of the sampled fields were recorded on a $35 \mathrm{~mm}$ electron microscope film of which the individual negatives were projected onto a screen at a final magnification of $\times 14,000$. A quadratic lattice grid was superimposed at random position onto each projected image. The total number of points falling onto profiles of the phagocytised particles $[\mathrm{P}(\mathrm{p})]$ and the entire cell $[\mathrm{P}(\mathrm{c})]$ were counted. An estimator of the volume density of the phagocytised particles $[\mathrm{Vv}(\mathrm{p}, \mathrm{c})]$ was then calculated as follows:

$$
\mathrm{Vv}(\mathrm{p}, \mathrm{c})=\mathrm{P}(\mathrm{p}) \times \mathrm{P}(\mathrm{c})^{-1}
$$

Statistical analysis of the data. The student t-test was used to compare the values on the duck and the rabbit in the various experiments. The level of significance was set at $\mathrm{p} \leq 0.05$

\section{RESULTS}

The average volume of PBS instilled and recovered from the respiratory tract of a rabbit was 125 and $106 \pm 7 \mathrm{ml}$ respectively. This represents a recovery rate of $85 \pm 5 \%$. In ducks, the average volume of PBS instilled and recovered from the lung-air-sac system was $2021 \pm 215 \mathrm{ml}$ and $1805 \pm$ $207 \mathrm{ml}$ (Table I). This represents a recovery rate of $89 \pm 3 \%$. The animals have comparable body mass $(\mathrm{p} \geq 0.05)$ with a mean body mass of $2 \pm 0.3 \mathrm{~kg}$ and $2.1 \pm 0.22 \mathrm{~kg}$ for the rabbit and the duck respectively (Table I). The lavage fluids recovered from the respiratory systems of the ducks and the rabbits contained surface respiratory macrophages, and epithelial cells presumed to have desquamated from the lining of the respiratory tracts. The epithelial cells were either ciliated or non ciliated (Fig. 3). Ultrastructurally, the duck and the rabbit SM were similar. Typically, they had filopodial extensions and variably electron dense cytoplsamic vesicular bodies (Fig. 3).

The rabbit SM exhibited a higher in vitro viability $(\mathrm{p} \leq 0.05)$ than the duck SM. The mean in vitro viability of the rabbit SM was $97 \pm 1 \%$ while that of the duck SM was $86 \pm 4 \%$ for the same period. Despite having equivalent body masses, ducks had significantly $(\mathrm{p} \leq 0.05)$ fewer SM harvested by pulmonary lavage than the rabbits. Ducks had a mean number of $1.1 \times 10^{6} \pm 148780 \mathrm{SM}$ while the rabbits had a mean number of $1.5 \times 10^{7} \pm 911362 \mathrm{SM}$ (Table II and Fig. 1). In the rabbits, the number of SM decreased steadily with progressive washes but in the ducks, there was progressive increase in the number of SM during the first three lavages (Fig. 2).

The mean diameter of the duck SM $(11 \pm 1.1 \mu \mathrm{m})$ was not significantly different $(\mathrm{p} \geq 0.05)$ from that of the rabbits SM $(13 \pm 1.3 \mu \mathrm{m})$ (Table III). Quantitative estimation of the loading of the SM with polystyrene particles showed that the duck SM, of which the phagocytised particles formed a volume density of $20 \%$ of the volume of a SM, took up significantly $(\mathrm{p} \leq 0.05)$ more particles than the rabbit SM in which the volume density of the phagocytised particles formed $9 \%$ (Table III and Fig. 4). 
MUTUA, P. M.; GICHERU, M. M.; MAKANYA, A. N. \& KIAMA, S. G. Comparative quantitative and qualitative attributes of the surface respiratory macrophages in the domestic duck and the rabbit. Int. J. Morphol., 29(2):353-362, 2011.

Table I. Volume of the phosphate, buffered saline (PBS) instilled in the respiratory systems of the rabbits and the ducks, the volume recovered, and the recovery rate.

\begin{tabular}{lcccc}
\hline Animal & Body Mass (Kg) & Instilled fluid $(\mathrm{ml})$ & Recovered fluid $(\mathrm{ml})$ & Recovery rate $(\%)$ \\
\hline Rabbit 1 & 2 & 125 & 100 & 80 \\
Rabbit 2 & 2 & 125 & 110 & 88 \\
Rabbit 3 & 1.8 & 125 & 98 & 78 \\
Rabbit 4 & 1.8 & 125 & 114 & 91 \\
Rabbit 5 & 2.2 & 125 & 112 & 90 \\
Rabbit 6 & 1.8 & 125 & 96 & 77 \\
Rabbit 7 & 2.5 & 125 & 110 & 88 \\
Mean & 2 & 125 & 106 & 85 \\
SD & 0.26 & - & 7.4 & 6.0 \\
& & & & 95 \\
Duck 1 & 2 & 2050 & 1950 & 90 \\
Duck 2 & 2 & 1670 & 1500 & 87 \\
Duck 3 & 1.8 & 2070 & 1800 & 88 \\
Duck 4 & 2 & 1960 & 1725 & 86 \\
Duck 5 & 2.2 & 1870 & 1610 & 88 \\
Duck 6 & 2.5 & 2320 & 2040 & 91 \\
Duck 7 & 2.2 & 2205 & 2010 & 89 \\
Mean & 2.1 & 2021 & 1805 & 3 \\
SD & 0.22 & 215 & 207 & \\
\hline
\end{tabular}

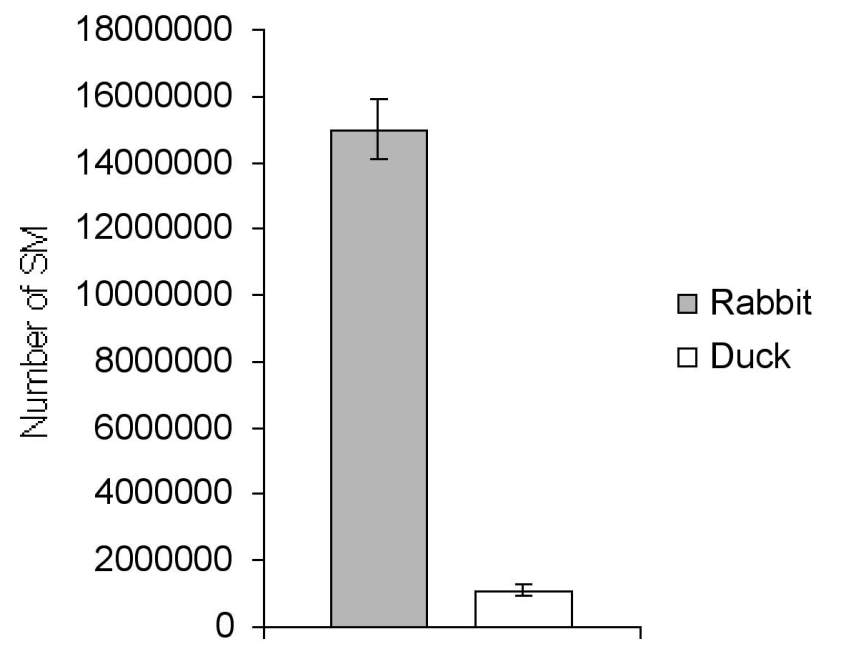

Fig. 1. Comparison of the average number of SM recovered by pulmonary lavage of the respiratory systems of the rabbit and the duck. Bars show standard deviations.

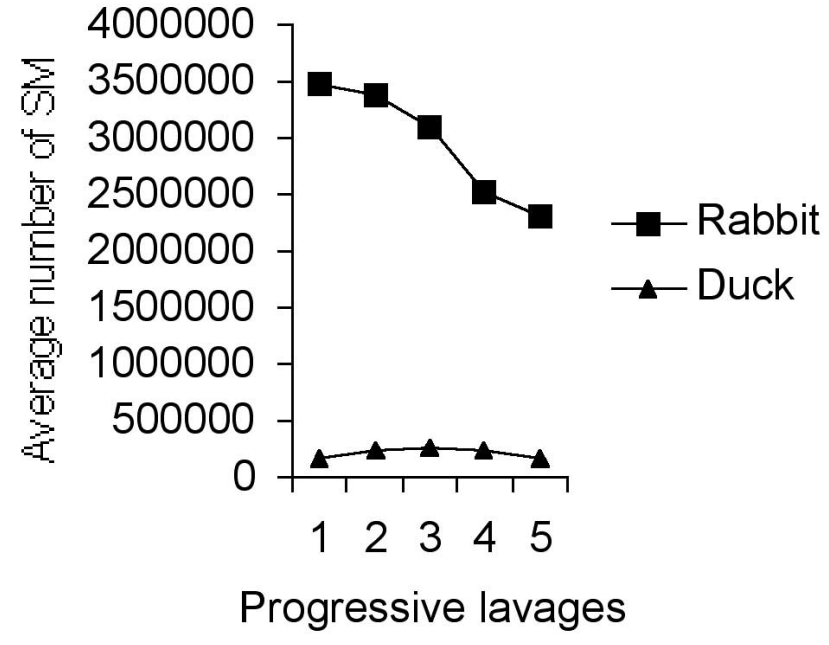

Fig. 2. Comparison of the average number of SM recovered from the rabbit and the duck respiratory systems by pulmonary lavage during five progressive lavages. 

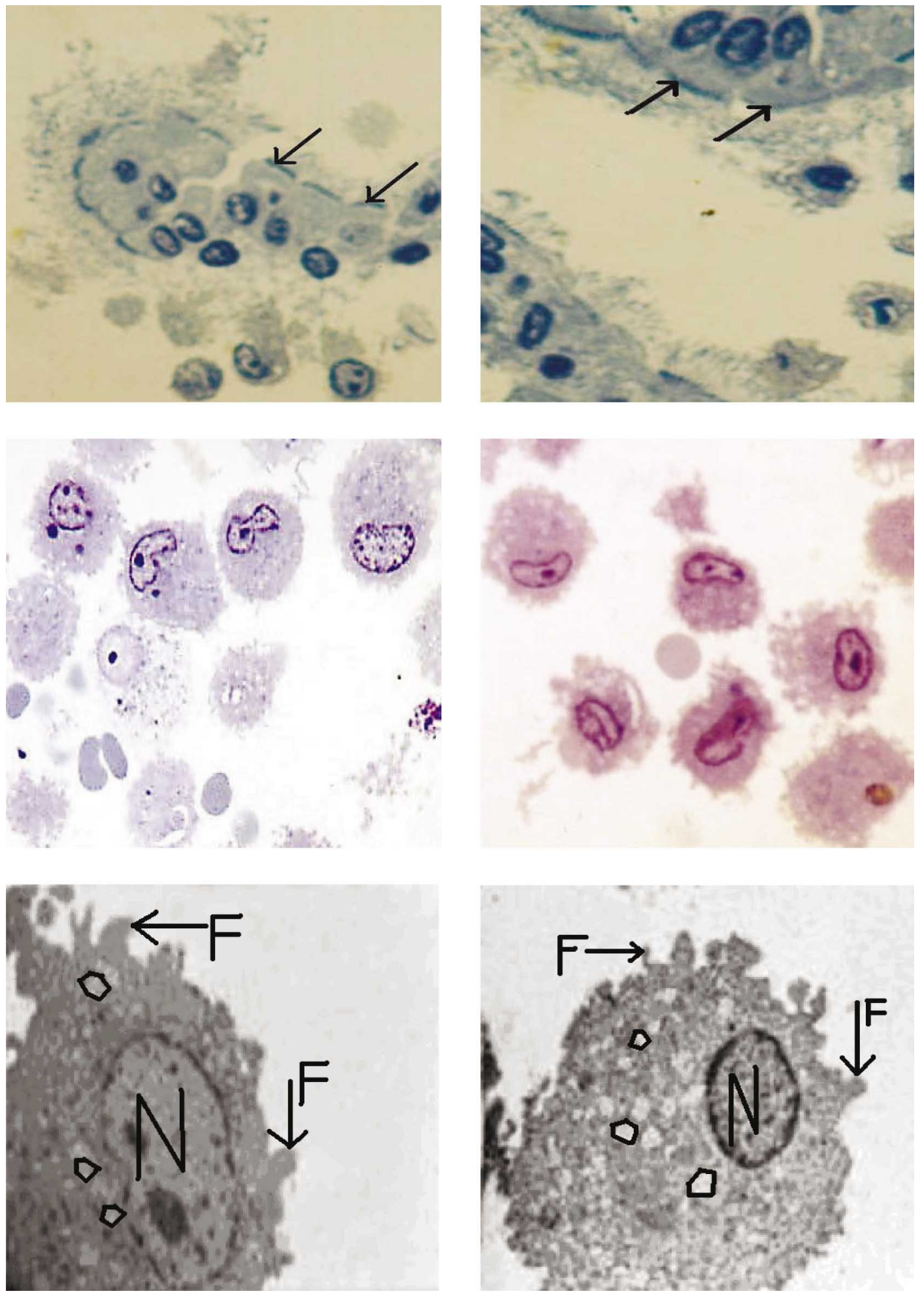

Fig. 3. Top, a-b are light micrographs of the rabbit and the duck epithelial cells, cilia (arrows). Middle, c-d are light micrographs of the rabbit and the duck SM recovered by pulmonary lavage of the rabbit and duck respiratory systems. In e-f (bottom) are electron micrographs of the rabbit and the duck SM with eccentric nucleus (N), filopodia (F), and cytoplasmic vesicles (encircled). 

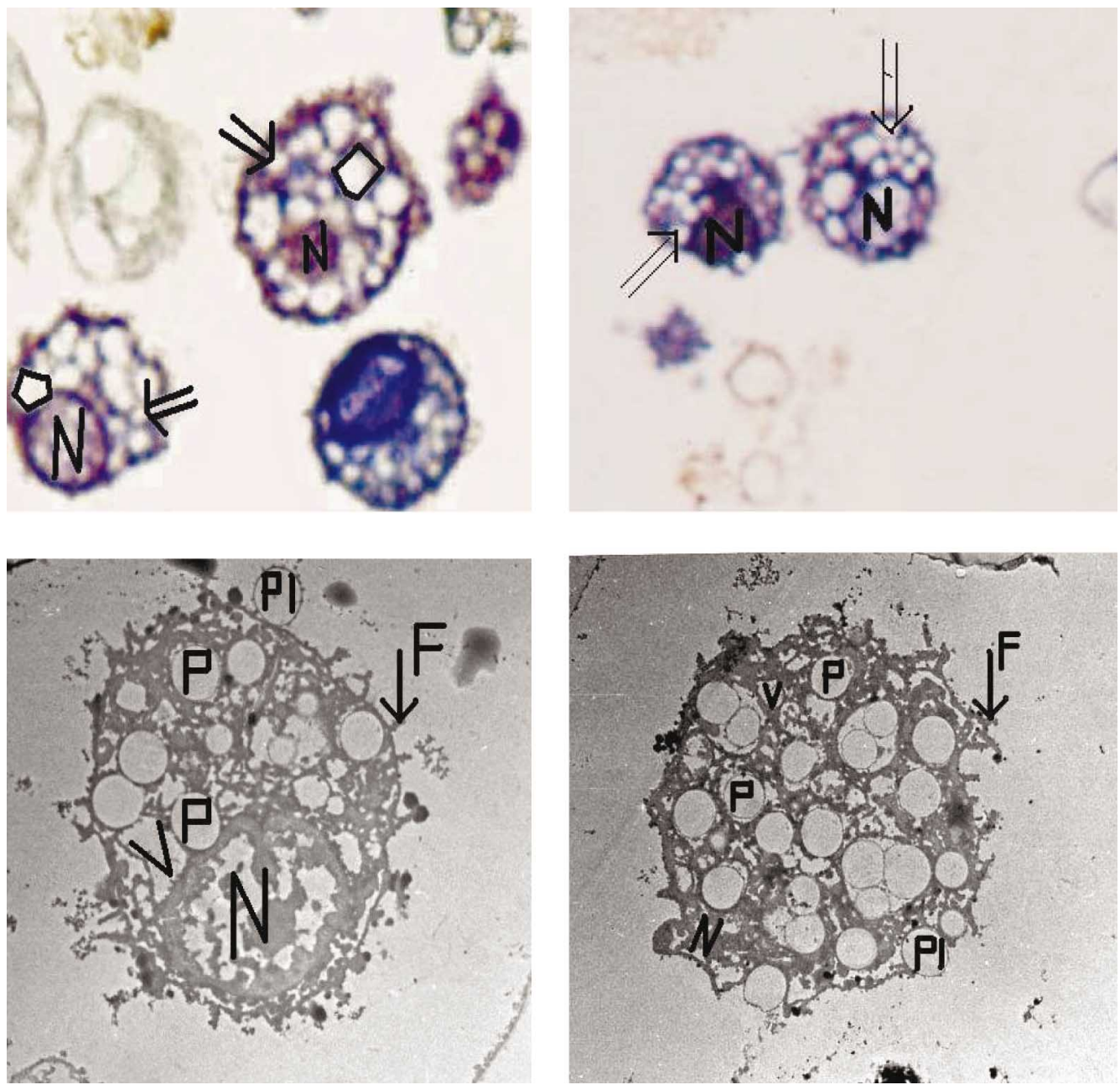

Fig. 4. Top, a-b are light micrographs of the rabbit and the duck SM with internalized particles (arrows), encircled areas show vacuoles while $\mathrm{N}$ show eccentric nucleus. The bottom, c-d are electron micrographs of the rabbit and the duck $\mathrm{SM}$ with $\mathrm{P}$-internalized particles, $\mathrm{N}$ - the nucleus, $\mathrm{V}$ - vacuoles, and F-the filopodia. The particles on the surface of the cell membrane are shown as PI and these particles have thick dark rim on their surface which is lacking in the internalized particles.
Table II Number of surface respiratory macrophages harvested by pulmonary lavage of the duck and the rabbit respiratory systems.

\begin{tabular}{lcc}
\hline Animal & Body Mass (Kg) & Total Number of SM (x106) \\
\hline Rabbit 1 & 2 & 16.425 \\
Rabbit 2 & 2 & 15.38 \\
Rabbit 3 & 1.8 & 14.5 \\
Rabbit 4 & 1.8 & 15.62 \\
Rabbit 5 & 2.2 & 13.6125 \\
Rabbit 6 & 1.8 & 15.125 \\
Rabbit 7 & 2.5 & 14.5125 \\
Mean & 2 & 15.025 \\
SD & 0.26 & - \\
& & \\
Duck 1 & 2 & 1.275 \\
Duck 2 & 2 & 1.15 \\
Duck 3 & 1.8 & 1.1125 \\
Duck 4 & 2 & 0.9 \\
Duck 5 & 2.2 & 0.9375 \\
Duck 6 & 2.5 & 1.05 \\
Duck 7 & 2.2 & 1.275 \\
Mean & 2.1 & 1.1 \\
SD & 0.22 & 0.14878 \\
\hline
\end{tabular}

Table III. Diameters of the SM and volume density of phagocytised particles in SM of the rabbit and the duck.

\begin{tabular}{lcccc}
\hline $\begin{array}{c}\text { Number } \\
\text { of } \\
\text { samples }\end{array}$ & $\begin{array}{c}\text { Diameters } \\
\text { of the } \\
\text { rabbit SM } \\
(\mu \mathrm{m})\end{array}$ & $\begin{array}{c}\text { Diameters } \\
\text { of the } \\
\text { duck SM } \\
(\mu \mathrm{m})\end{array}$ & $\begin{array}{c}\text { Volume } \\
\text { density of } \\
\text { particles } \\
\text { in the } \\
\text { duck SM } \\
(\%)\end{array}$ & $\begin{array}{c}\text { Volume } \\
\text { density of } \\
\text { particles } \\
\text { in the } \\
\text { rabbit } \\
\text { SM }(\%)\end{array}$ \\
\hline 1 & 12 & 9 & 23 & 9 \\
2 & 15 & 11 & 20 & 10 \\
3 & 12 & 10 & 19 & 9 \\
4 & 14 & 11 & 22 & 8 \\
5 & 13 & 12 & 18 & 7 \\
Mean & 13 & 11 & 20 & 9 \\
SD & 1.3 & 1.1 & 2.1 & 1.1 \\
\hline
\end{tabular}




\section{DISCUSSION}

This study confirms that, quantitatively, the surface respiratory macrophages (SM) harvested by respiratory lavage in the avian respiratory system are by far much fewer in comparison to SM harvested by the same method in mammals of similar body weight. In the duck, Anas platyrhynchos, the average number of SM is $1.1 \times 10^{6}$ while in the domestic rabbit, Oryctologus cuniculus, the average number of SM is $1.5 \times 10^{7}$, this represents fourteen times more, the number of SM in the rabbit respiratory system compared to the number of SM in the duck respiratory system. Scarcity of avian surface respiratory macrophages (Ficken et al., 1986; Maina \& Cowley) and even lack of them (Qureshi et al., 1994; Klika et al.; Lorz \& López) have been reported in normal steady respiratory systems of poultry. Ficken et al. and Maina \& Cowley reported $1.15 \times 10^{6}$ and $1.6 \times 10^{5}$ avian SM in the turkey, Melleagris gallopavo and the rock dove, Columba livia. Toth et al. (1987) reported $2.5 \times 10^{5}$ in the domestic fowl. In mammals such as the rat and the hamster, yields of $8.5 \times 10^{6}$ (Brian \& Frank, 1968) and $4.64 \times 10^{6}$ (Kavet \& Brain, 1977) have been reported respectively.

The knowledge of the cell types from normal lungs of laboratory animals forms the basis of experimental investigation of the inflammatory diseases in humans (Novakov \& Peshev, 2005). In 30 year-old human beings, $1.5 \times 10^{7}$ and $5.2 \times 10^{7}$ macrophages were harvested by bronchopulmonary lavage from a non-smoker and a smoker respectively (Im Hof et al., 1990). Ours is the first study to quantify the number of free surface respiratory macrophages recovered by bronchopulmonary lavage of normal steady state respiratory system of rabbits and the information is crucial in development of an appropriate model for human lung defense systems. Furthermore, the number of SM harvested from the rabbit by pulmonary lavage is similar to the number of SM recovered from the 30-year-old nonsmoker by Im Hof et al.

Birds have a blood-gas barrier that is $56-67 \%$ thinner and a respiratory surface area that is $15 \%$ more extensive than mammals of equivalent body mass (Maina \& Cowley). Assuming that the defense capacities of the SM in mammals and birds are comparable, this would mean that in birds, either an auxiliary defense line that complements the defense activity of the scarce avian SM occurs and /or that compared with the mammalian SM, the avian SM are innately more competent in phagocytising. In this study, a higher avian in vitro phagocytic capacity was demonstrated by the duck SM which phagocytized two times more the amount of particles phagocytized by the rabbit SM yet the SM, are of compara- ble diameters and by extrapolation similar volumes. The ability to phagocytose more particles by duck SM in comparison to rabbit SM is important because these cells have not only been demonstrated to be fewer, but also to be present in the parabronchi where a ciliated epithelium is lacking (Mensah \& Brain, 1982; Stearns et al., 1986, 1987; Maina \& Cowley; Nganpiep \& Maina). In our previous comparative in vitro study on particle interaction with the chicken and the rat SM, epithelial cells, and the erythrocytes, we reported that chicken SM, which have comparable diameters and therefore volume with rat SM, phagocytized four times the number of particles the rat SM phagocytized and that chicken red blood cells present in the lavage fluid phagocytized particles unlike the rat blood cells that did not phagocytose any particles. The phagocytic capacity of the chicken SM was ascertained to be $23 \%$ while that of the rat SM was found to be 5\% (Kiama et al., 2008). Notable phagocytic differences have been reported in the pulmonary macrophages of various mammalian species. The hamsters SM have been reported to have higher phagocytic capacity than the rat SM but the rat SM exhibits a higher phagocytic capacity than the mice SM (Warheit \& Hartsky).

Influx of avian SM onto the surface of the lung has been demonstrated (Ficken et al.). In this study, there was substantial increase of SM during the first three respiratory lavages of the ducks but the SM decreased in the subsequent lavages. This increase of SM may have emanated through efflux from the subepithelial compartment or even the vascular system itself. Other studies support influx of SM into the lung-air sac system of birds. Toth et al. (1987) observed that the proportion of SM increased more than five fold within 24 hours in Pasteurella multocida vaccinated birds. They concluded that influx of SM should play a very important defensive role against pathogens since it occurs before onset of clinical signs and that the normal steadystate avian respiratory system is refractory to presence of inert stimulants but responds efficiently to replicating bacteria, leading to a very rapid influx of large numbers of activated SM with high phagocytic capacities. The efficiency of translocation of subepithelial macrophages to the epithelial surface could be a significant factor in the lack of large numbers of resident macrophages on the respiratory surface of the avian lung. Furthermore, the epithelial cells lining the atrial muscles, the atrial floor and the infundibulae have been shown to be phagocytic and that the cells have high concentrations of hydrolytic enzymes. These avian pulmonary cellular defense mechanisms render birds to have high rate of particulate clearance within the respiratory system (Stearns et al., 1987). Mensah \& Brain reported that $46 \%$ of particles deposited in the respiratory tract of the domestic fowl were cleared within 1 hour. This is faster than in mammals and reptiles where, for example, in the hamster 
and the horse, clearance of particulate matter occurs within 24 hours (Gehr et al., 1990). In mammals phagocytes migrate over a relatively short distance of $200-300 \mu \mathrm{m}$ from the alveoli to reach the terminal bronchioles from where the cells and the engulfed particles are mechanically transported by the mucociliary escalator system to the pharynx. The parabrochial lumen where avian SM exist is lined by a non -secretory, non-stratified and non-ciliated epithelium (McLelland, 1989; Lopez, 1995; Pastor \& Calvo, 1995). An SM would have to travel over a distance of about 10000 $\mu \mathrm{m}$ to reach the nearest parts of the secondary bronchi of the avian lung that have a ciliated epithelium. To survive such a distance, the cell would have to be exceptionally motile and resilient (Kiama et al., 2008).

Ultrastructurally, the avian surface respiratory macrophages and the mammalian alveolar macrophages recovered from the respiratory system by lavage are similar. In this study, the duck SM and the rabbit SM had eccentric nuclei, filopodial extensions, and cytoplasmic vesicular bodies.

In conclusion, based on this study, the avian SM harvested by respiratory lavage are quantitatively fewer but qualitatively more efficient in in-vitro phagocytosis than the mammalian SM. Domestic birds are kept in crowded spaces which may contain high concentrations of particulates and toxic gases. Viable particle concentrations as high as $2.4 ¥$ 105 have been reported (Anderson et al., 1966). Stress under such unnatural conditions may compromise the immunological robustness and cellular body defenses. The avian cellular defense may not be inadequate but the intense management and husbandry practices could have led to human-induced 'directed evolutionary pressure' on birds and the avian immunological and cellular defenses may not have had time to adjust. The innate defenses of the avian respiratory system need not necessarily be poor or inferior in comparison to the mammalian pulmonary cellular defense.

\section{ACKNOWLEDGEMENTS}

We are grateful to Louise Bowditch and Robert Grant for funding this study. Excellent technical support was provided by Messers Jackson Mugweru, Jackson Gachoka, and Peter Kinguru, all from the department of Veterinary Anatomy and Physiology, Chiromo campus, University of Nairobi.

MUTUA, P. M.; GICHERU, M. M.; MAKANYA, A. N. \& KIAMA, S. G. Atributos cualitativos, cuantitativos y comparativos de los macrófagos de la superficie respiratoria en el pato doméstico y el conejo. Int. J. Morphol., 29(2):353-362, 2011.

RESUMEN: En los mamíferos, los macrófagos de la superficie respiratoria (SM) son conocidos por jugar el papel más importante en la protección del sistema respiratorio, proporcionando la primera línea de defensa en contra de agentes patógenos y envolviendo las partículas de aire respirado. Se ha informado que el sistema de defensa celular pulmonar de las aves domésticas es insuficiente. En particular, el bajo número de SM, e incluso las células del sistema respiratorio de las aves domésticas, en un ambiente sano, se ha asociado con susceptibilidad a enfermedades respiratorias. En un esfuerzo para resolver la controversia existente, los atributos cuantitativos y cualitativos de los macrófagos de la superficie respiratoria del pato doméstico y el conejo doméstico fueron comparados en las mismas condiciones experimentales. Cuantitativamente, los SM del conejo fueron en promedio aproximadamente catorce veces más que los SM en el pato. Los SM se encontraron con un diámetro comparable, al medir alrededor de 12 micras en el pato y 13 micras en el conejo. Del mismo modo, en el pato y el conejo los SM eran estructuralmente similares. Por lo general, correspondieron a células granulares con extensiones filopodiales y organismos electrodensos variables en el citoplasma. La capacidad fagocítica medida utilizando partículas de poliestireno reveló que los SM del pato tenían una mayor capacidad fagocítica que el conejo. La densidad de volumen de las partículas de poliestireno envueltas, es decir, el volumen de las partículas por unidad de volumen se estimó en $20 \%$ en el pato y $9 \%$ en el conejo. Estos resultados sugieren que el número comparativamente bajo de los SM en las aves domésticas puede contribuir a su susceptibilidad a enfermedades. Sin embargo, dada la alta capacidad fagocítica de los SM aviares, la susceptibilidad de las aves domésticas no puede deberse solamente a la escasez de SM, sino a algunos otros factores pueden estar involucrados, como la exposición persistente de las aves a partículas, las cuales se sabe reducen la robustez de los SM.

PALABRAS CLAVE: Aviar; Defensa celular; Pulmón; Fagocitosis; Conejo; Macrófagos de superficie.

\section{REFERENCES}

Anderson, D. P.; Beard, C. W. \& Hanson, R. P. Influence of poultry house dust, ammonia, and carbon dioxide on the resistance of chickens to Newcastle disease virus. Avian. Dis., 10(2):177-88, 1966.
Brain, J. D. Environmental lung disease: exposures and mechanisms. Chest, 109(3):74S-8, 1996.

Brain, J. D. \& Frank, N. R. Recovery of free cells from rat 
lungs by repeated washings. J. Appl. Physiol., 25(1):639, 1968.

Brown, R. E.; Brain, J. D. \& Wang, N. The avian respiratory system: a unique model for studies of respiratory toxicosis and for monitoring air quality. Environ. Health Perspect., 105(2):188-200, 1997.

Brunekreef, B. \& Holgate, S. T. Air pollution and health. Lancet, 360(9341):1233-42, 2002.

Currie, R. J. Ascites in poultry: recent investigations. Avian Pathol., 28(4):313-26, 1999.

Dockery, D. W.; Schwartz, J. \& Spengler, J. D. Air pollution and daily mortality: associations with particulates and acid aerosols. Environ Res., 59(2):362-73, 1992.

Fagerland, J. A. \& Arp, L. H. A morphologic study of bronchus-associated lymphoid tissue in turkeys. Am. $J$. Anat., 189(1):24-34, 1990.

Ficken, M. D.; Edwards, J. F. \& Lay, J. C. Induction, collection, and partial characterization of induced respiratory macrophages of the turkey. Avian Dis., 30(4):766-71, 1986.

Fulton, R. M.; Reed, W. M. \& DeNicola, D. B. Light microscopic and ultrastructural characterization of cells recovered by respiratory-tract lavage of 2- and 6-weekold chickens. Avian Dis., 34(1):87-98, 1990.

Gehr, P.; Green, F. H.; Geiser, M.; Im Hof, V.; Lee, M. M. \& Schürch, S. Airway surfactant, a primary defense barrier: mechanical and immunological aspects. J. Aerosol Med., 9(2):163-81, 1996.

Gehr, P.; Schurch, S.; Geisser, M. \& Im Hof, V. Retention and clearance mechanism of inhaled particles. J. Aerosol Sci., 21(1):S491-6, 1990.

Geiser, M.; Matter, M.; Maye, I.; Im Hof, V.; Gehr, P. \& Schürch, S. Influence of airspace geometry and surfactant on the retention of man-made vitreous fibers (MMVF 10a). Environ. Health Perspect., 111(7):895-901, 2003.

Godfrey, R. W. Human airway epithelial tight junctions. Microsc. Res. Tech., 38(5):488-99, 1997.

Harkema, J. R.; Marassy, A.; Geoge, J.; Hyde, D. M. \& Plopper, C. Epithelial cells of conducting airways: a species comparison. In: Lung Biology in Health and Disease. The Airway Epithelium. Farmer, S. G. \& Hay,
D. W.P. (Eds.). New York, Marcel Dekker Inc., 1991. pp.339.

Im Hof, V.; Klauser, M. \& Gehr, P. Phagocytic properties and organelle motility of pulmonary macrophages from smokers and nonsmokers estimated in vitro by magnetometric means. Eur. Respir. J., 3(2):157-62, 1990.

Kavet, R. I. \& Brain, J. D. Phagocytosis: quantification of rates and intercellular heterogeneity. J. Appl. Physiol., 42(3):432-7, 1977.

Kiama, S. G.; Adekunle, J. S. \& Maina, J. N. Comparative in vitro study of interactions between particles and respiratory surface macrophages, erythrocytes, and epithelial cells of the chicken and the rat. J. Anat., 213(4):452-63, 2008.

Kiama, S. G.; Cochand, L.; Karlsson, L.; Nicod, L. P. \& Gehr, P. Evaluation of phagocytic activity in human monocytederived dendritic cells. J. Aerosol Med., 14(3):289-99, 2001.

Klika, E.; Scheuermann, D. W.; De Groodt-Lasseel, M. H.; Bazantova, I. \& Switka, A. Pulmonary macrophages in birds (barn owl, Tyto tyto alba), domestic fowl (Gallus gallus $\mathrm{f}$. domestica), quail (Coturnix coturnix), and pigeons (Columbia livia). Anat. Rec., 246(1):87-97, 1996.

Lippmann, M. \& Schlesinger, R. B. Interspecies comparisons of particle deposition and mucociliary clearance in tracheobronchial airways. J. Toxicol. Environ. Health, 13(2-3):441-69, 1984.

Lopez, J. Anatomy and histology of the lung and air sacs of birds. In: Histology, Ultrastructure, and Immunochemistry of the Respiratory Organs in Non-Mammalian Vertebrates. Pastor, L. M. (ed.). Murcia, Universidad de Murcia, 1995. pp. 179-233.

Lorz, C. \& López, J. Incidence of air pollution in the pulmonary surfactant system of the pigeon (Columba livia). Anat. Rec., 249(2):206-12, 1997.

Maina, J. N. Comparative pulmonary morphology and morphometry: The functional design of respiratory systems. In: Advances in comparative and Environmental Physiology. Gilles, R. (Ed.). Heidelberg, Springer-Verlag, 1994. pp.111-232.

Maina, J. N. \& Cowley, H. M. Ultrastructural characterization of the pulmonary cellular defences in the lung of a bird, the rock dove, Columba livia. Proc. Biol. Sci., 265(1405):1567-72, 1998. 
Maina, J. N. \& West, J. B. Thin but strong! The dilemma inherent in the structure design of the blood-gas barrier: comparative functional and evolutionary perspectives. Physiol. Rev., 85:811-44, 2005.

McLelland, J. Anatomy of the lungs and air sacs. In: Form and Function in Birds. King, A. S. \& McLelland, J. (Eds.). London, Academic Press, 1989. pp. 221-279

Mensah, G. A. \& Brain, J. D. Deposition and clearance of inhaled aerosol in the respiratory tract of chickens. $J$. Appl. Physiol., 53(6):1423-8, 1982.

Nganpiep, L. N. \& Maina, J. N. Composite cellular defence stratagem in the avian respiratory system: functional morphology of the free (surface) macrophages and specialized pulmonary epithelia. J. Anat., 200(5):499516, 2002.

Nicod, L. P. Lung defences: an overview. Eur. Respir. Rev., 14:45-50, 2005.

Novakov, I. P. \& Peshev, Z. V. Cell types in the normal pleural fluid from rabbits. Trakia J. Sci., 3(1):22-5, 2005.

Oberdörster, G.; Ferin, J. \& Lehnert, B. E. Correlation between particle size, in vivo particle persistence, and lung injury. Environ. Health Perspect., 102(5):173-9, 1994.

Pastor, L. M. \& Calvo, A. The extrapulmonary airways in birds. In Histology, Ultrastructure and Immunochemistry of the Respiratory Organs on NonMammalian vertebrates. Pastor, L. M. (ed.). Murcia, Murcia University Press, 1995. pp.159-73.

Peters, A.; Wichmann, H. E.; Tuch, T.; Heinrich, J. \& Heyder, J. Respiratory effects are associated with the number of ultrafine particles. Am. J. Respir. Crit. Care Med., 155(4):1376-83, 1997.

Qureshi, M. A.; Marsh, J. A.; Dietert, R. R.; Sung, Y. J.; Nicolas-Bolnet, C. \& Petitte, J. N. Profiles of chicken macrophage effector functions. Poult. Sci., 73(7):102734, 1994.

Reese, S.; Dalamani, G. \& Kaspers, B. The avian lungassociated immune system: a review. Vet. Res., 37(3):311-24, 2006.

Schürch, S.; Gehr, P.; Im Hof, V.; Geiser, M. \& Green, F. Surfactant displaces particles toward the epithelium in airways and alveoli. Respir. Physiol., 80(1):17-32, 1990.
Schwartz, J. Air pollution and daily mortality in Birmingham, Alabama. Am. J. Epidemiol., 137:1136-47, 1993.

Skerrett, S. J. Host defenses against respiratory infection. Med. Clin. North. Am., 78(5):941-66, 1994.

Spira, A. Disorders of the respiratory system. In Disease of Cage and Aviary Birds. Rosskopf, W. \& Woerpel, R. (Ed). 3rd Ed. Baltimore, Williams \& Wilkins, 1996. pp.415-28.

Stearns, R. C.; Barnas, G. M.; Walski, M. \& Brain, J. D. Phagocytosis in the gas exchange region of avian lungs. Fed. Proc., 45:959, 1986.

Stearns, R. C.; Barnas, G. M.; Walski, M. \& Brain, J. D. Deposition and phagocytosis of inhaled particles in the gas exchange region of the duck, Anas platyrhynchos. Respir. Physiol., 67(1):23-36, 1987.

Toth, T. E.; Pyle, R. H.; Caceci, T.; Siegel, P. B. \& Ochs, D. Cellular defense of the avian respiratory system: influx and nonopsonic phagocytosis by respiratory phagocytes activated by Pasteurella multocida. Infect. Immun., 56(5):1171-9, 1988.

Toth, T. E.; Siegel, P. \& Veit, H. Cellular defense of the avian respiratory system. Influx of phagocytes: elicitation versus activation. Avian Dis., 31(4):861-7, 1987.

van Oss, C. J. Phagocytosis: an overview. Methods Enzymol., 132:3-15, 1986.

Warheit, D. B. \& Hartsky, M. A. Role of alveolar macrophage chemotaxis and phagocytosis in pulmonary clearance responses to inhaled particles: comparisons among rodent species. Microsc. Res. Tech., 26(5):412-22, 1993.

Correspondence to:

Patrick Mutua

Department of Zoological Sciences

Kenyatta University

P.O BOX 339-90137

Kibwezi - KENYA

Tel +254727677738

Email: patmbuvi@gmail.com

Received:13-12-2010

Accepted:19-03-2011 